\title{
Seasonal changes of B-chromosome frequencies within the population of Apodemus flavicollis (Rodentia) on Cer mountain in Yugoslavia
}

\author{
Mladen VUJOŠEVIĆ and Jelena BLAGOJEVIĆ
}

\begin{abstract}
Vujošević M. and Blagojević J. 1995. Seasonal changes of B-chromosome frequencies within the population of Apodemus flavicollis (Rodentia) on Cer mountain in Yugoslavia. Acta Theriologica 40: 131-137.

A change of B-chromosome frequencies in the population of Apodemus flavicollis (Melchior, 1834) from Cer mountain in Yugoslavia was studied. Five samples were collected during 1989. Specimens with Bs were present in all samples with frequencies ranging from 0.22 to 0.39 . Differences between frequencies of animals with $\mathrm{Bs}$ in successive samples were not statistically significant. The change in the population size $(n)$ was positively correlated with variation in frequency of animals with Bs $\left(r_{\mathrm{P}}\right.$ $=0.81)$, but negatively with frequency of Bs per $\mathrm{B}$ carrying animals $\left(r_{\mathrm{P}}=-0.65\right)$. A analysis of variance of external body measures and some cranial characters showed no significant differences between animals with and without Bs.
\end{abstract}

Department of Genetics, Institute for Biological Research "Siniša Stanković", 29 novembra 142, 11060 Belgrade, Yugoslavia

Key words: Apodemus flavicollis, B chromosomes, population size

\section{Introduction}

In plants and insects, species possessing $\mathrm{B}$ chromosomes are widespread. According to data summarized by Jones and Rees (1982) and Jones and Puertas (1992) more than 1300 species of plants and over 500 animal species had Bs. In mammals the occurrence of B chromosomes seems to be relatively uncommon. They were found in 34 species only (Vujoševic 1993). Mostly they are found in rodent species. At present 29 species of rodents were found to possess B chromosomes (Civitelli et al. 1989). Within the genus Apodemus there are three species possessing Bs. The B chromosome polymorphism of yellow necked mice Apodemus flavicollis (Melichior, 1834) in Yugoslavia is geographically very widespread, almost all populations studied are characterized by the presence of individuals with B chromosomes (Vujošević and Živković 1987, Vujošević et al. 1991). The frequencies of animals with $B$ chromosomes are rather different between the populations studied, ranging from 0 to 0.63 . The highest number of Bs found in one animal is 5 for Yugoslav populations (Blagojević and Vujošević 1991). 
All Bs are acrocentric chromosomes with sizes of the 5 smallest pairs of the normal complement. In the population from Jastrebac mountain the proportion of animals with Bs stayed constant over a five years period (Vujošević 1992). The purpose of this study was to survey whether the polymorphism of Bs in populations of A. flavicollis is stable or is actively changing during one season, and if it is dependent on population size.

\section{Material and methods}

Samples of yellow necked mice were taken in Yugoslavia on Cer mountain (Querceto-carpinetum association), at $379 \mathrm{~m}$ altitude. A total of 54 animals were trapped in March, May, July, September and November 1989. For statistical analyses September and November samples were pooled because the November sample was too small ( 4 animals). One hundred "Longworth" traps were arranged in 4 rows at 10 meters distance between each trap and between rows. The trapping always lasted 4 nights. In the morning animals were removed from traps and transported to the laboratory. Each time the sampling was done in the same way, but the next sampling area was more than 200 meters distant from the previous one, which is greater than home range for this species (Kučera 1970). The size of population was estimated by the removal method (Hayne 1949). Chromosomal slide preparation was performed directly from bone marrow cells using standard procedures, and treated afterwards with G- and C-banding techniques (Arrighi and Hsu 1971, Seabright 1971). Animals were measured for some external characters: total length, body length, tail length, body weight, left and right hind foot length and left and right ear length. The cranial characters measured were length of left and right maxillary tooth row, zygomatic length, mandible length, length of mandible tooth row, height of mandible, interorbital breadth, skull width, skull length, skull height, nasal length. Statistical analyses of these characters were performed using one way ANOVA. Differences between frequencies of animals with Bs in successive samples were tested by Fisher exact test using Statistix (version 2.01987 ).

\section{Results}

The normal karyotype of Apodemus flavicollis consists of 48 acrocentric chromosomes (Matthey 1936). Cytological analysis showed that animals with Bs were present in all samples studied (Table 1). As in previous studies (Vujošević et al. 1991) all Bs were small acrocentrics with G- and C-band distribution not different

Table 1. Number of animals with (B1, B2, B3) and without B (B0) chromosomes and frequency of animals with B's (f-B) in four samples.

\begin{tabular}{|c|c|c|c|c|c|c|c|c|c|}
\hline \multirow{2}{*}{ Sample } & \multicolumn{4}{|c|}{ Males } & \multicolumn{3}{|c|}{ Females } & \multirow{2}{*}{ Total } & \multirow{2}{*}{$f-B$} \\
\hline & B0 & B1 & B2 & B3 & B0 & B1 & B2 & & \\
\hline March & 8 & 3 & 2 & - & 3 & 1 & 1 & 18 & 0.39 \\
\hline May & 4 & - & - & - & 3 & 1 & 1 & 9 & 0.22 \\
\hline July & 3 & 1 & - & 1 & 4 & - & - & 9 & 0.22 \\
\hline Sep-Nov & 4 & 4 & 1 & - & 8 & - & 1 & 18 & 0.33 \\
\hline Total & 19 & 8 & 3 & 1 & 18 & 2 & 3 & 54 & 0.29 \\
\hline
\end{tabular}




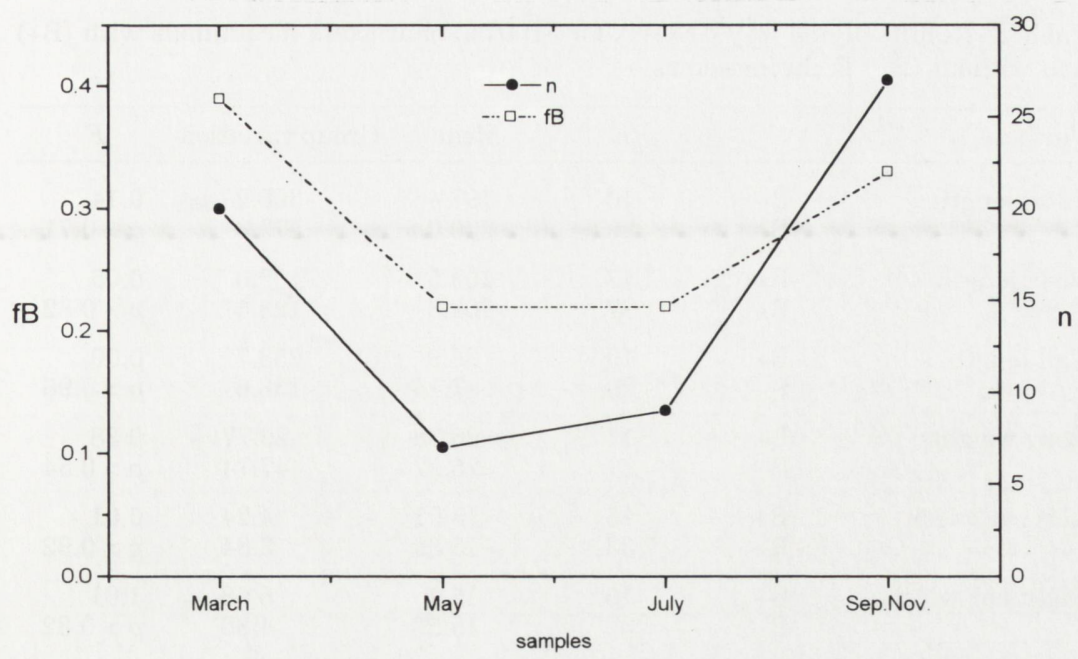

Fig. 1. Changes in frequency of specimens with Bs (fB) and changes in size of population $(n)$ of Apodemus flavicollis on Cer mountain during 1989.

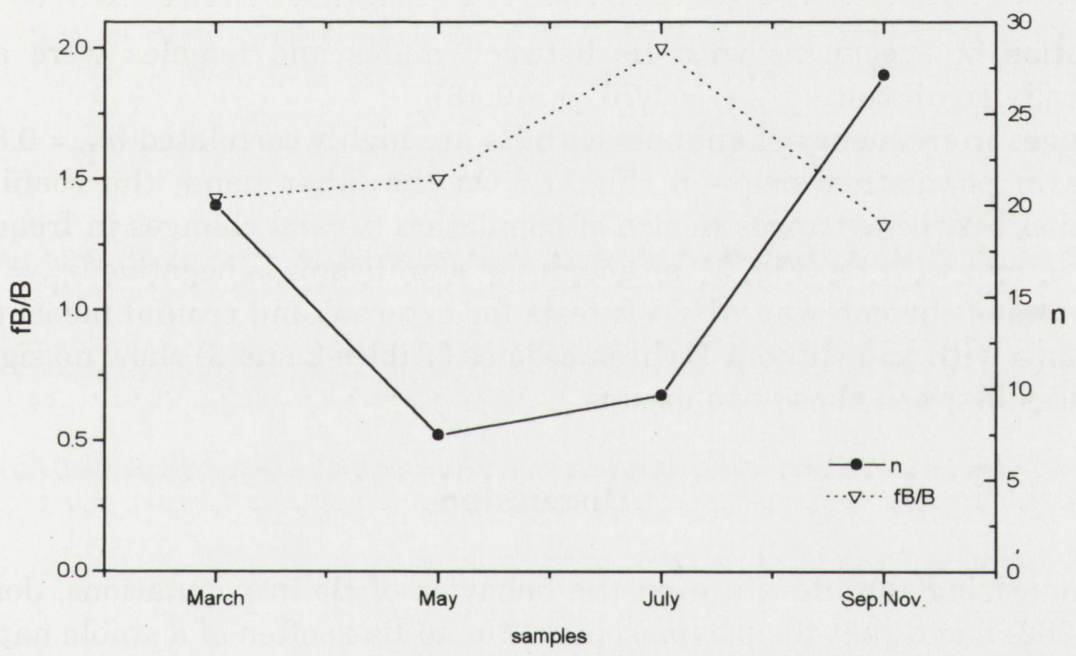

Fig. 2. Changes in number of $\mathrm{Bs}$ per animal with $\mathrm{Bs}(\mathrm{fB} / \mathrm{B})$ and changes in size of population $(n)$ of Apodemus flavicollis on Cer mountain during 1989.

from that of A chromosomes. The frequency of animals with B chromosomes ranged from 0.22 to 0.39 during the study period. Differences between frequencies of animals with $\mathrm{Bs}$ in successive samples were not statistically significant. The most of animals with B chromosomes (58.8\%) showed only one B while $35.3 \%$ showed 2 Bs. Only one specimen with $3 \mathrm{~B}$ chromosomes was found. Differences in the 
Table 2. Results of one way ANOVA for external characters for animals with (B+) and without (B-) B chromosomes.

\begin{tabular}{llcccl}
\hline Variable & & $n$ & Mean & Group variation & \multicolumn{1}{c}{$F$} \\
\hline Total length & B+ & 10 & 197.4 & 305.2 & 0.14 \\
& B- & 29 & 200.0 & 379.3 & $p>0.71$ \\
Body length & B+ & 17 & 103.5 & 109.0 & 0.05 \\
& B- & 37 & 102.8 & 123.5 & $p>0.82$ \\
Tail length & B+ & 10 & 96.9 & 253.7 & 0.00 \\
& B- & 29 & 97.14 & 138.6 & $p>0.96$ \\
Body weight & B+ & 17 & 26.38 & 29.77 & 0.38 \\
& B- & 37 & 25.22 & 47.74 & $p>0.54$ \\
Left ear width & B+ & 15 & 15.91 & 4.04 & 0.01 \\
& B- & 33 & 15.85 & 3.84 & $p>0.92$ \\
Right ear width & B+ & 16 & 15.79 & 6.08 & 1.01 \\
& B- & 32 & 16.50 & 4.80 & $p>0.32$ \\
Left foot length & B+ & 17 & 21.81 & 0.99 & 0.08 \\
& B- & 35 & 21.73 & 0.74 & $p>0.78$ \\
Right foot length & B+ & 17 & 22.02 & 0.91 & 2.14 \\
& B- & 37 & 21.6 & 1.01 & $p>0.15$ \\
\hline
\end{tabular}

distribution of specimens with Bs between males and females were also not statistically significant $\left(\chi^{2} p(1)=1.76, p>0.18\right)$.

Changes in frequency of animals with Bs are highly correlated $\left(r_{\mathrm{P}}=0.81\right)$ with changes in population size $-n$ (Fig. 1). On the other hand, the coefficient of correlation between changes in size of population $(n)$ and changes in frequency of Bs per animal with Bs (Fig. 2), although not significant, is negative $\left(r_{\mathrm{P}}=-0.65\right)$. The results of the one way ANOVA tests for external and cranial measurements for animals with and without B chromosomes (Tables 2 and 3) show no significant differences between these two groups.

\section{Discussion}

Summarizing the literature on the behavior of Bs in populations, Jones and Rees (1982) found that the polymorphism due to Bs is often of a stable nature and equilibrium is reached partly by the rate and manner of their transmission from parent to offspring, partly by selection which operates upon the variation in phenotype due to their activity. Only few examples of changes in frequencies related to seasonal changes were reported. Kayano et al. (1970) found no significant differences in frequencies of grasshopper Acrida lata males with B chromosomes at different times during one year. Robinson and Hewitt (1976) detected three periods of differential selection pro and contra B chromosomes in grasshopper Myrmeleotettix maculatus during a year. Furthermore there are very few examples of attempts to find a correlation between the presence of Bs and morphological 
Table 3. Results of one way ANOVA for cranial measurments for animals with $(\mathrm{B}+)$ and without $(\mathrm{B}-)$ B chromosomes. L1, R1 - length of left and right maxillar tooth row, L2, R2 - zygomatic length, L3, R3 - mandible length, L4, R4 - length of mandible tooth row, L5, R5 - height of mandible, OW - interorbital breadth, SW - skull width, SL - skull length, SH - skull height, NL - nasal length.

\begin{tabular}{|c|c|c|c|c|c|}
\hline Variable & & $n$ & Mean & Group variation & $F$ \\
\hline L1 & $\begin{array}{l}\mathrm{B}+ \\
\mathrm{B}-\end{array}$ & $\begin{array}{l}17 \\
36\end{array}$ & $\begin{array}{l}4.15 \\
4.18\end{array}$ & $\begin{array}{l}0.02 \\
0.02\end{array}$ & $\begin{array}{l}0.32 \\
p>0.57\end{array}$ \\
\hline $\mathrm{R} 1$ & $\begin{array}{l}\mathrm{B}+ \\
\mathrm{B}-\end{array}$ & $\begin{array}{l}17 \\
36\end{array}$ & $\begin{array}{l}4.16 \\
4.14\end{array}$ & $\begin{array}{l}0.02 \\
0.02\end{array}$ & $\begin{array}{l}0.09 \\
p>0.76\end{array}$ \\
\hline L2 & $\begin{array}{l}\mathrm{B}+ \\
\mathrm{B}-\end{array}$ & $\begin{array}{l}17 \\
36\end{array}$ & $\begin{array}{l}9.75 \\
9.65\end{array}$ & $\begin{array}{l}0.38 \\
0.34\end{array}$ & $\begin{array}{l}0.31 \\
p>0.58\end{array}$ \\
\hline $\mathrm{R} 2$ & $\begin{array}{l}\mathrm{B}+ \\
\mathrm{B}-\end{array}$ & $\begin{array}{l}17 \\
36\end{array}$ & $\begin{array}{l}9.77 \\
9.67\end{array}$ & $\begin{array}{l}0.40 \\
0.31\end{array}$ & $\begin{array}{l}0.36 \\
p>0.55\end{array}$ \\
\hline L3 & $\begin{array}{l}\mathrm{B}+ \\
\mathrm{B}-\end{array}$ & $\begin{array}{l}17 \\
36\end{array}$ & $\begin{array}{l}15.33 \\
15.28\end{array}$ & $\begin{array}{l}1.31 \\
0.96\end{array}$ & $\begin{array}{l}0.02 \\
p>0.88\end{array}$ \\
\hline R3 & $\begin{array}{l}\mathrm{B}+ \\
\mathrm{B}-\end{array}$ & $\begin{array}{l}17 \\
36\end{array}$ & $\begin{array}{l}14.93 \\
15.06\end{array}$ & $\begin{array}{l}1.41 \\
0.71\end{array}$ & $\begin{array}{l}0.23 \\
p>0.63\end{array}$ \\
\hline L4 & $\begin{array}{l}\mathrm{B}+ \\
\mathrm{B}-\end{array}$ & $\begin{array}{l}17 \\
36\end{array}$ & $\begin{array}{l}4.18 \\
4.22\end{array}$ & $\begin{array}{l}0.03 \\
0.02\end{array}$ & $\begin{array}{l}0.57 \\
p>0.45\end{array}$ \\
\hline $\mathrm{R} 4$ & $\begin{array}{l}\mathrm{B}+ \\
\mathrm{B}-\end{array}$ & $\begin{array}{l}17 \\
36\end{array}$ & $\begin{array}{l}4.16 \\
4.20\end{array}$ & $\begin{array}{l}0.02 \\
0.02\end{array}$ & $\begin{array}{l}1.13 \\
p>0.29\end{array}$ \\
\hline L5 & $\begin{array}{l}\mathrm{B}+ \\
\mathrm{B}-\end{array}$ & $\begin{array}{l}17 \\
36\end{array}$ & $\begin{array}{l}7.31 \\
7.35\end{array}$ & $\begin{array}{l}0.59 \\
0.52\end{array}$ & $\begin{array}{l}0.03 \\
p>0.86\end{array}$ \\
\hline R5 & $\begin{array}{l}\mathrm{B}+ \\
\mathrm{B}-\end{array}$ & $\begin{array}{l}17 \\
36\end{array}$ & $\begin{array}{l}7.27 \\
7.31\end{array}$ & $\begin{array}{l}0.53 \\
0.44\end{array}$ & $\begin{array}{l}0.04 \\
p>0.85\end{array}$ \\
\hline OW & $\begin{array}{l}\mathrm{B}+ \\
\mathrm{B}-\end{array}$ & $\begin{array}{l}17 \\
36\end{array}$ & $\begin{array}{l}4.34 \\
4.33\end{array}$ & $\begin{array}{l}0.03 \\
0.02\end{array}$ & $\begin{array}{l}0.08 \\
p>0.78\end{array}$ \\
\hline SW & $\begin{array}{l}\mathrm{B}+ \\
\mathrm{B}-\end{array}$ & $\begin{array}{l}17 \\
34\end{array}$ & $\begin{array}{l}12.93 \\
12.89\end{array}$ & $\begin{array}{l}1.45 \\
0.96\end{array}$ & $\begin{array}{l}0.01 \\
p>0.91\end{array}$ \\
\hline SL & $\begin{array}{l}\mathrm{B}+ \\
\mathrm{B}-\end{array}$ & $\begin{array}{l}17 \\
36\end{array}$ & $\begin{array}{l}26.90 \\
26.84\end{array}$ & $\begin{array}{l}3.12 \\
2.19\end{array}$ & $\begin{array}{l}0.02 \\
p>0.90\end{array}$ \\
\hline SH & $\begin{array}{l}\mathrm{B}+ \\
\mathrm{B}-\end{array}$ & $\begin{array}{l}17 \\
36\end{array}$ & $\begin{array}{l}7.66 \\
7.76\end{array}$ & $\begin{array}{l}0.22 \\
0.23\end{array}$ & $\begin{array}{l}0.54 \\
p>0.46\end{array}$ \\
\hline NL & $\begin{array}{l}\mathrm{B}+ \\
\mathrm{B}-\end{array}$ & $\begin{array}{l}17 \\
36\end{array}$ & $\begin{array}{l}9.52 \\
9.61\end{array}$ & $\begin{array}{l}1.19 \\
0.74\end{array}$ & $\begin{array}{l}0.09 \\
p>0.76\end{array}$ \\
\hline
\end{tabular}

changes in mammals. All have failed, except for a correlation with length of rostrum in Reithrodontomys megelotis which used only a small number of specimens (Shellhammer 1969). In Apodemus flavicollis no correlation between the presence of Bs and external and cranial characters was found, maybe due to the small sample sizes. 
In the case of A. flavicollis from Cer mountain, the frequency of specimens with B chromosomes in the first sample collected in March is considered to represent the result of winter survival. From March to May the frequency of specimens with $\mathrm{Bs}$ is decreasing. In the next sample the proportion of animals with B chromosomes stay at the same level, and then the last sample, before winter, shows an increase. Pooled November and September samples give a frequency of animals with Bs (0.33) quite similar to frequency in March sample (0.39). The frequency of Bs per animal with B chromosomes does not behave in the same manner (Fig. 2). In general, a decrease of population size is accompanied by an increase of frequency of Bs per B containing animal. But in the July sample this increase is a result of presence of only one specimen with $3 \mathrm{~B}$ chromosomes. The results suggest that animals with one B may survive better in the population when the size of population is larger, and animals with more than one B are favored in conditions when population size is very low, but this possibility needs further support. It could be seen that during this study the size of population of A. flavicollis was at a relatively low level. The highest number of animals at Cer mountain was 21.9 per ha while at the Jastrebac mountain there were 378.8 animals per ha during the same year (Blagojević and Vujošević, in press). It is clear that two peaks of abundance are existing in spring and autumn. The same peaks could be seen for frequency of animals with Bs. Similar situation was found in grasshopper $M$. maculatus (Robinson and Hewitt 1976) where the decrease of $\mathrm{fB}$ between autumn and spring was accompanied by increase of number of specimens with two and more than two B chromosomes. The same changes were found in chives Allium schoenoprasum (Holmes and Bougourd 1989) between seeds and seedlings during a year.

A kind of equilibrium, which was designated as imperfect by White (1973), seems to occur in many natural populations that have several generations in a year. In the case studied this means that frequency of specimens with Bs is varying through the year, but these seasonal cycles, to some extent, are repeated yearly. Thus the frequencies of Bs through the year could be significantly different but their values between years stay the same. This is the case with specimens of A. flavicollis (Vujošević 1992) where the frequency of animals with Bs sampled always in the middle June was constant over 5 years period. White (1973) thinks that such seasonal cycles could be good evidence for the action of selection on the cytogenetic constitution of population.

\section{References}

Arrighi F. E. and Hsu T. C. 1971. Localization of heterochromatin in human chromosomes. Cytogenetics 10: 1-86.

Blagojević J. and Vujošević M. 1991. Supernumerary chromosomes of Apodemus flavicollis (Rodentia, Mammalia). The highest number of B-chromosomes. Arhiv bioloških Nauka 43 (3-4): 31-32.

Civitelli M. V., Consentino P. and Capanna E. 1989. Inter and intraindividual chromosome variability in Thamnomys (Grammomys) gazellae (Rodentia, Muridae) B-chromosomes and structural heteromorphisms. Genetica 79: 93-105. 
Hayne D. W. 1949. Two methods of estimating population from trapping records. Journal of Mammalogy 30: 399-411.

Holmes D. S. and Bougourd S. M. 1989. B-chromosome selection in Allium schoenoprasum. I. Natural populations. Heredity 63: 83-87.

Jones R. N. and Rees H. 1982. B Chromosomes. Academic Press, London: 1-266.

Jones R. N. and Puertas J. M. 1993. The B-chromosomes of Rye (Secale cereale L.). [In: Frontiers in plant science research. K. K. Dhir and T. S. Sareen, eds]. Bhagwati Enterprises, Delhi (India): 81-112.

Kayano H., Sannomiya M. and Nakamura K. 1970. Cytogenetic studies on natural populations of Acrida lata. I. Local variation in the frequency of B-chromosomes. Heredity 25: 113-122.

Kučera E. 1970. Über den Aktionsraum der Gelbhalsmaus, Apodemus flavicollis (Melchior, 1834) in Zentralbohmen. Säugetirkundliche Mitteilungen 18: 1-6.

Matthey R. 1936. La formule chromosomiale et les heterochromosomes chez les Apodemus europeens. Zeitschrift für Zellforschung und Mikroskopische Anatomie 25: 50-515.

Robinson P. M. and Hewitt G. M. 1976. Annual cycles in the incidence of B chromosomes in the grasshopper Myrmeleotettix maculatus (Acrididae-Orthoptera). Heredity 36: 399-412.

Seabright M. 1971. A rapid banding technique for human chromosomes. Lancet 11: 971-972.

Shellhammer H. S. 1969. Supernumerary chromosomes of the harvest mouse, Reithrodontomys megalotis. Chromosoma 27: 102-108.

Vujošević M. 1992. B-chromosome polymorphism in Apodemus flavicollis (Rodentia, Mammalia) during five years. Caryologia 45 (3-4): 347-352.

Vujošević M. 1993. B-chromosomes in mammals. Genetika 25 (3): 247-258.

Vujošević M. and Živković S. 1987. Numerical chromosome polymorphism in Apodemus flavicollis and A. sylvaticus (Mammalia: Rodentia) caused by supernumerary chromosomes. Acta Veterinaria 37 (2-3): 81-92.

Vujošević M., Blagojević J., Radosavljević J. and Bejaković D. 1991. B chromosome polymorphism in populations of Apodemus flavicollis in Yugoslavia. Genetica 83: 167-170.

White M. J. D. 1973. Animal cytology and evolution. University Press, Cambridge: 233.

Received 15 March 1994, accepted 6 February 1995. 